\title{
ANTIBODY LEVELS TO HANTAVIRUS IN INHABITANTS OF WESTERN SANTA CATARINA STATE, BRAZIL
}

William Marciel de SOUZA(1), Alex Martins MACHADO(1), Geonildo Rodrigo DISNER(2), Everton BOFF(2), Aline Rafaela da Silva Rodrigues MACHADO(1), Michelly de PADUA(1), Luiz Tadeu Moraes FIGUEIREDO(1) \& Gustavo Borba de MIRANDA(2)

\begin{abstract}
SUMMARY
Hantavirus cardiopulmonary syndrome (HCPS) is an infectious disease caused by hantaviruses of the family Bunyaviridae, and is transmitted by aerosols of excreta of infected rodents. The aim of the present study was to determine antibody levels to hantavirus in the population that lives at frontier of Brazil and Argentina. Participated of the study 405 individuals living in the municipalities of Bandeirante, Santa Helena, Princesa and Tunapolis, state of Santa Catarina, Brazil. IgG antibodies to hantavirus were analyzed in sera by an ELISA that uses a recombinant $\mathrm{N}$ protein of Araraquara hantavirus as antigen. The results were also confirmed by immunofluorescent test. Eight individuals showed antibodies to hantavirus (1.97\% positivity), with serum titers ranging from 100 to 800. Six seropositives were males, older than 30 years and farmers. Our results reinforce previous data on hantavirus circulation and human infections in the southern border of Brazil with Argentina.
\end{abstract}

KEYWORDS: Hantavirus; Epidemiology; Brazil; Argentina; Santa Catarina.

\section{INTRODUCTION}

Hantavirus is a genus in the family Bunyaviridae. These viruses cause two serious illnesses: the hemorrhagic fever with a renal syndrome (HFRS) in Europe and Asia, and the hantavirus cardiopulmonary syndrome (HCPS) in the Americas, which is characterized by respiratory failure, shock and high case fatality ${ }^{5,10,14}$. Hantaviruses are zoonotic viruses, in general transmitted to humans by inhalation of aerosols of excreta by direct contact with infected rodents, although there are reports documenting the spread of Andes virus from human to human ${ }^{19,22}$.

In the Americas, hantaviruses have been identified in Argentina, Bolivia, Chile, Costa Rica, Paraguay, Panama, Mexico, Venezuela, Peru, United States and Uruguay ${ }^{2}$. Presently, more than 40 American hantavirus genotypes are known and nearly half of them are pathogenic for humans ${ }^{10}$. In Brazil, seven hantavirus genotypes are known. Two of them, Jabora and Rio Mearim virus, were not related to disease in humans. The others, Juquitiba, Araraquara, Laguna Negra-like, Castelo dos Sonhos, and Anajatuba have been responsible for more than 1440 cases of HPS reported in Brazil since 1993, with a $39 \%$ case fatality ratio ${ }^{1,10,14}$.

HCPS is an emerging public health problem in Brazil that is related to a simplification of ecosystems diminishing biodiversity, agricultural expansion and urban populations ${ }^{20}$. It increased the density of opportunistic species such as rodents which are reservoirs of hantavirus, thus increasing the frequency of their interactions with humans, and the occurrence of $\mathrm{HCPS}^{13}$.

The state of Santa Catarina has an economy based on agriculture and is presently the second state in number of HCPS reported cases in Brazil, 233 cases, with a $27 \%$ case fatality ratio ${ }^{1}$. Currently, two known strains circulate in the state: Juquitiba associated to Oligoryzomys nigripes and Jabora related to Akodon montensis ${ }^{21,28}$.

Although, HCPS cases were not reported in the west of the state of Santa Catarina, a previous study in this region showed individuals previously infected by hantavirus in two municipalities ${ }^{27}$. Thus, this work has been done in order to obtain better information on antibody levels to hantavirus in the west of the state Santa Catarina, at the border with northern Argentina.

\section{METHODS}

Studied population: The study was carried out in November of 2011. A number of 405 adult inhabitants of urban and rural areas of four municipalities of the state of Santa Catarina participated of the study: 94 from Bandeirante located at latitude $26^{\circ} 46^{\prime} 07^{\prime \prime}$ south and longitude $53^{\circ} 38^{\prime} 18^{\prime \prime}$ west, with a population of 2,906; 100 from Princesa located at latitude $26^{\circ} 26^{\prime} 31^{\prime \prime}$ south and longitude $53^{\circ} 35^{\prime}$ '54" west, with a population of 2,758; 96 from Santa Helena located at latitude 26 $56^{\prime} 15$ south and

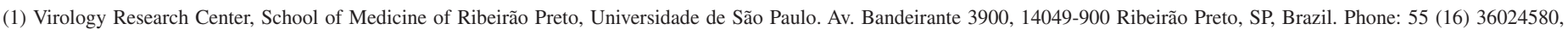
E-mails: wmarciel@hotmail.com; alexmmachado@usp.br; alinerafaelasr@yahoo.com.br; michellydepadua@usp.br; 1tmfigue@fmrp.usp.br;

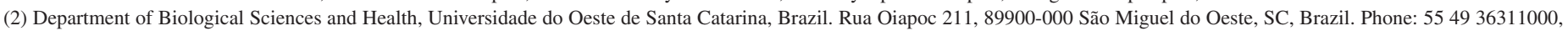
E-mails: geonildog@yahoo.com.br; farmamed@mhnet.com.br; gustavo.miranda@unoesc.edu.br

Correspondence to: William Marciel de Souza, Av. Bandeirante 3900, 14049-900 Ribeirão Preto, SP, Brasil. Phone: 55 16 36024580. E-mail: wmarciel@ hotmail.com 
SOUZA, W.M.; MACHADO, A.M.; DISNER, G.R.; BOFF, E.; MACHADO, A.R.S.R.; PADUA, M.; FIGUEIREDO, L.T.M. \& MIRANDA, G.B. - Antibody levels to hantavirus in inhabitants of western Santa Catarina State, Brazil. Rev. Inst. Med. Trop. Sao Paulo, 54(4): 193-6, 2012.

longitude 53'37'09" west, with population of 2,393 and 115 from Tunapolis located at latitude $26^{\circ} 58^{\prime} 08^{\prime \prime}$ ' south and longitude $53^{\circ} 38^{\prime} 21^{\prime \prime}$ west and a population of 4,633 individuals. All towns have agricultural economic activity and are located in the border with Argentina (Fig. 1). Serum samples and general information were collected from all participants. This study was approved by the ethics committee and research protocol No. 073/2009 of Universidade do Oeste de Santa Catarina, Brazil.

IgG-ELISA to hantavirus: Serum samples at 1:100 dilution were tested in duplicate by an indirect IgG enzyme linked immunosorbent assay (ELISA), using a $\mathrm{N}$ recombinant protein of Araraquara hantavirus

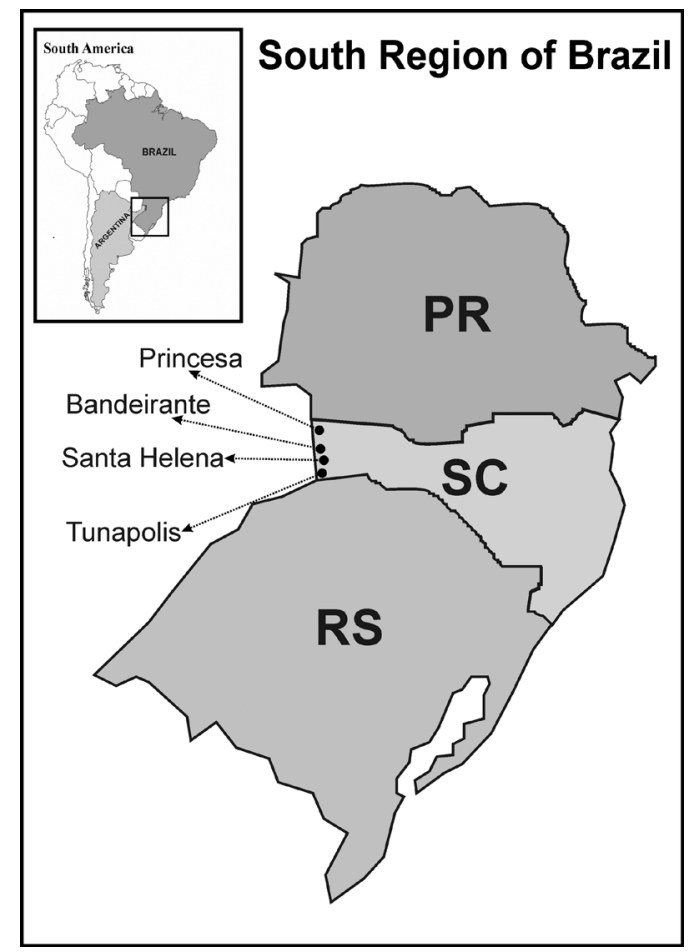

Fig. 1 - Location of four towns participating in the study: Princesa, Bandeirante, Santa Helena and Tunapolis. PR: Parana State; SC: Santa Catarina State; RS: Rio Grande do Sul State. produced in $E$. coli and negative control (a protein extract of E. coli, not containing the plasmid encoding the recombinant protein), as previously reported $^{7,9}$. Values were expressed as the optical density (OD) obtained with Araraquara $\mathrm{N}$ antigen minus the $\mathrm{OD}$ values for the control antigens. The cut-off value of the test was determined by ODs mean added to three standard deviations of the ODs obtained from at least four negative-control sera. After the test, all positive samples were diluted 1:100 to 1:1,600 and tested by the ELISA in order to determine serum titers to hantavirus ${ }^{16,17}$.

Immunofluorescence: IgG positive sera in the ELISA were also tested by an indirect immunofluorescence assay (IFA) using Vero E6 cells infected with Rio Mamore hantavirus prefixed in spots slides. Serum samples were diluted 1:100 in saline buffer and the Anti-Human IgG FITCs (Sigma, USA) was diluted 1:2000 in saline buffer. The IFA was performed as previously described ${ }^{15,27}$.

\section{RESULTS}

Sera of eight of the 450 participants of the study presented $\mathrm{IgG}$ antibodies to hantavirus (1.97\% positivity) at titers of 100 to 800 . All positive sera in the ELISA for hantavirus, were also positive by IFA (Table 1). Seropositivity per county was, $2.12 \%$ (2/94) in Bandeirante, $1.04 \%$ (1/96) in Santa Helena, 2\% (2/100) in Princesa and 2.60\% (3/115) in Tunapolis.

Among the seropositive participants, seven were more than 30 years old (87.5\% of the seropositives), six were men (75\%) and also six were farmers (75\%), one was a government official and the other was a student. All of them reported contact with wild rodents around their residences (Table 1). Five of the farmer seropositive participants lived in the rural area.

It was not possible to associate previous diseases reported by the eight seropositive participants with hantavirus infection and/or disease.

\section{DISCUSSION}

The detection of $1.97 \%$ seropositive inhabitants at the four studied municipalities of western Santa Catarina State, shows that hantavirus

Table 1

Cases of seroreagents to hantavirus according to city, gender, age, occupation, home, presence of rodent and IgG antibody title

\begin{tabular}{|c|c|c|c|c|c|c|c|}
\hline Sample & City & Gender & Age & Occupation & Home & $\begin{array}{c}\text { Presence of } \\
\text { rodent }^{*}\end{array}$ & Title \\
\hline S35 & Santa Helena & Male & 46 years & Agricultural worker & Rural & yes & 200 \\
\hline $\mathrm{T} 1$ & Tunapólis & Male & 61 years & Agricultural worker & Urban & yes & 100 \\
\hline $\mathrm{T} 15$ & Tunapólis & Male & 32 years & Agricultural worker & Rural & yes & 100 \\
\hline $\mathrm{T} 42$ & Tunapólis & Male & 51 years & Agricultural worker & Rural & yes & 200 \\
\hline P5 & Princesa & Male & 52 years & Agricultural worker & Rural & yes & 400 \\
\hline P37 & Princesa & Female & 51 years & Governamental official & Urban & yes & 800 \\
\hline B56 & Bandeirante & Female & 18 years & Student & Urban & yes & 400 \\
\hline B57 & Bandeirante & Male & 76 years & Agricultural worker & Rural & yes & 200 \\
\hline
\end{tabular}

* Related presence of rodent in around the house. 
SOUZA, W.M.; MACHADO, A.M.; DISNER, G.R.; BOFF, E.; MACHADO, A.R.S.R.; PADUA, M.; FIGUEIREDO, L.T.M. \& MIRANDA, G.B. - Antibody levels to hantavirus in inhabitants of western Santa Catarina State, Brazil. Rev. Inst. Med. Trop. Sao Paulo, 54(4): 193-6, 2012.

infections are probably occurring in that region. These antibody levels are similar to those reported in other South American studies using IgG-ELISA where seropositivity ranged from $0.2 \%$ to $14.3 \%$ 2,6,12,18,24,25,27. Therefore, hantavirus infections are probably occurring in the studied municipalities despite of no HCPS reported cases. Curiously, close to this region, at the other side of the border, in northeastern Argentina, there is a high number of HCPS reported $\operatorname{cases}^{23}$.

None of seropositive participants reported previous symptoms compatible with HCPS. It is possible that they have presented an oligosymptomatic infection. The low serum titer positives could be because of long time hantavirus infection ${ }^{5}$. It is also possible that the seropositive participants were infected by a less virulent hantavirus than Juquitiba, which is supposed to occur in the area. Therefore, Jabora, a hantavirus that has not been reported causing human disease, was also reported in the state of Santa Catarina ${ }^{21}$, and Andes hantavirus have been reported close to the study area in Argentina ${ }^{23}$. Further studies looking for virus in acute febrile illness patients and/or in wild rodents could help to know what hantavirus causes human infection in the region ${ }^{24,25}$.

The hantavirus seropositive participants were mostly (75\%) male farmers over 30 years old. It corroborates other South American studies, reporting that this is the highest risk population for hantavirus infections ${ }^{4,18,29}$. Agricultural workers may have contact with hantavirus infected rodents during their daily tasks and become infected. However, the student and government official could also become infected by hantavirus during recreational activities in the field or in the residence since all seropositives reported contact with wild rodents around their residences ${ }^{8,10}$.

Currently, two hantavirus genotypes have been reported in the state of Santa Catarina, Juquitiba-Like virus associated to Oligoryzomys nigripes rodent and Jabora virus associated to Akodon montensis rodent ${ }^{21,28}$. In the region where this study was conducted, Oligoryzomys nigripes and Akodon montensi ${ }^{27}$ have been notified and at the other side of the border, in the province of Misiones, Argentina, Oligoryzomys flavescens rodent, the reservoir of Andes hantavirus, has been reported ${ }^{3}$.

In short, we show here that human infections by hantavirus occur in western Santa Catarina State at the border Brazil-Argentina and further studies are necessary to improve the study of human disease, an etiological agent and rodent reservoir.

\section{RESUMO}

\section{Níveis de anticorpos para hantavírus em habitantes da região Oeste de Santa Catarina, Brasil}

Síndrome Cardiopulmonar por Hantavírus (HCPS) é uma doença emergente, causada pelo gênero hantavírus membro da família Bunyaviridae, e são transmitidos aos humanos por aerossol de roedores infectados. O objetivo principal deste estudo foi determinar os níveis de anticorpos para hantavírus em uma população de residentes na fronteira do Brasil com a Argentina. Participaram deste estudo 405 indivíduos que moravam nos municípios de Bandeirante, Santa Helena, Princesa e Tunapólis, no estado de Santa Catarina, Brasil. Os anticorpos IgG para hantavírus foram analisados no soro por um ELISA que usa a nucleoproteína recombinante do vírus Araraquara como antígeno, posteriormente confirmados por imunofluorescência. Oito indivíduos apresentavam anticorpos para hantavírus (1.97\% positivo), com titulo entre 100 a 800 . Seis soropositivos foram homens, com idade superior a 30 anos e agricultores. Nossos resultados reforçam a circulação do hantavírus e infecção humana na fronteira do Brasil com a Argentina

\section{ACKNOWLEDGMENTS}

The municipal governments of Princesa, Bandeirante, Santa Helena and Tunapólis.

\section{FINANCIAL SUPPORT}

CNPq - Conselho Nacional de Pesquisa and FAPESP - Fundação de Amparo à Pesquisa do Estado de São Paulo.

\section{REFERENCES}

1. Brasil. Ministério da Saúde. [cited 2012, February 02]. Available from: www.saude. gov.br

2. Campos GM, Sousa RLM, Badra SJ, Pane C, Gomes UA, Figueiredo LTM. Serological survey of hantavirus in Jardinópolis county, Brazil. J Med Virol. 2003;71:417-22.

3. Donalisio MR, Peterson AT. Environmental factors affecting transmission risk for hantaviruses in forested portions of southern Brazil. Acta Trop. 2011;119:125-30.

4. Ferrer JF, Jonsson CB, Esteban E, Galligan D, Basombrio MA, Peralta-Ramos M, et al. High prevalence of hantavirus infection in Indian communities of the Paraguayan and Argentinean Gran Chaco. Am J Trop Med Hyg. 1998;59:438-44.

5. Figueiredo LTM. Febres hemorrágicas por vírus no Brasil. Rev Soc Bras Med Trop. 2006;39:203-10.

6. Figueiredo LTM, Morelli ML, Campos GM, Sousa R. Hantaviruses in São Paulo State, Brazil. Emerg Infect Dis. 2003;9:891-2.

7. Figueiredo LTM, Moreli ML, Borges AA, Figueiredo GG, Souza RLM, Aquino VH. Expression of a hantavirus $\mathrm{N}$ protein and its efficacy as antigen in immune assays. Braz J Med Biol Res. 2008;41:596-9.

8. Figueiredo LTM, Moreli ML, de Souza LM, Borges AA, Figueiredo GG, Machado AM, et al. Hantavirus pulmonary syndrome, Central Plateau, Southeastern, and Southern Brazil. Emerg Infect Dis. 2009;15: 561-7.

9. Figueiredo LTM, Moreli ML, Borges AA, Figueiredo GG, Bisordi I, Suzuki A, et al. Evaluation of an Enzyme-Linked Immunosorbent Assay based on Araraquara virus recombinant nucleocapsid protein. Am J Trop Med Hyg. 2009;81:273-6.

10. Hjelle B, Torres-Pérez F. Hantaviruses in the Americas and their role as emerging pathogens. Viruses. 2010;2:2559-86.

11. Hujakka H, Koistinen V, Kuronen I, Eerikäinen P, Parviainen M, Lundkvist A, et al. Diagnostic rapid tests for acute hantavirus infections: specific tests for Hantaan, Dobrava and Puumala viruses versus a hantavirus combination test. J Virol Methods. 2003;108:117-22.

12. Iversson LB, Da Rosa AP, Rosa MD, Lomar AV, Sasaki MG, LeDuc JW. Human infection by Hantavirus in southern and southeastern Brazil. Rev Assoc Med Bras. 1994;40:85-92.

13. Jaksic FM, Lima M. Myths and facts on ratadas: bamboo blooms, rainfall peaks and rodent outbreaks in South America. Austral Ecol. 2003;28:237-51.

14. Jonsson CB, Figueiredo LTM, Vapalahti O. A global perspective: Hantavirus ecology, epidemiology and disease. Clin Microbiol Rev. 2010;23:412-41. 
SOUZA, W.M.; MACHADO, A.M.; DISNER, G.R.; BOFF, E.; MACHADO, A.R.S.R.; PADUA, M.; FIGUEIREDO, L.T.M. \& MIRANDA, G.B. - Antibody levels to hantavirus in inhabitants of western Santa Catarina State, Brazil. Rev. Inst. Med. Trop. Sao Paulo, 54(4): 193-6, 2012.

15. LeDuc JW, Smith GA, Pinheiro FP, Vasconcelos PFC, Rosa EST, Maiztegui JI. Isolation of a hantaan-related virus from Brazilian rats and serologic evidence of its widespread distribution in South America. Am J Trop Med Hyg. 1985;34:810-5.

16. Machado AM, Figueiredo GG, Santos Jr S, Figueiredo LTM. Laboratory diagnosis of human hantavirus infection: novel insights and future potential. Future Virol. 2009;4:383-9.

17. Machado AM, Machado AR, Moreli ML, Ribeiro BM, Figueiredo LT, Wolff JL. Expression of recombinant Araraquara Hantavirus nucleoprotein in insect cells and its use as an antigen for immunodetection compared to the same antigen expressed in Escherichia coli. Virol J. 2011;8:218.

18. Máttar S, Parra M. Serologic evidence of Hantavirus infection in humans, Colombia. Emerg Infect Dis. 2004;10:2263-4

19. Martinez VP, Bellomo CM, Cacace ML, Suarez P, Bogni L, Padula PJ. Hantavirus pulmonary syndrome in Argentina, 1995-2008. Emerg Infect Dis. 2010;16:1853-60.

20. Mills JN. Regulation of rodent-borne viruses in the natural host: implication for human disease. Arch Virol. 2005;19(Suppl):45-57.

21. Oliveira RC, Padula PJ, Gomes R, Martinez VP, Bellano C, Bonvicino CR, et al. Genetic characterization of hantaviruses associated with sigmodontine rodents in an endemic area for hantavirus pulmonary syndrome in southern Brazil. Vector Borne Zoonotic Dis. 2011;11:301-14.

22. Padula PJ, Edelstein A, Miguel SD, López NM, Rossi CM, Rabinovich RD. Hantavirus pulmonary syndrome outbreak in Argentina: molecular evidence for person-to-person transmission of Andes virus. Virology. 1998:241:323-30.
23. Padula P, Martinez VP, Bellomo C, Maidana S, San Juan J, Tagliaferri P, et al. Pathogenic Hantaviruses, Northeastern Argentina and Eastern Paraguay. Emerg Infect Dis. 2007;13:1211-4.

24. Pini N, Levis S, Calderón G, Ramirez J, Bravo D, Lozano E, et al. Hantavirus infection in humans and rodents, northwestern Argentina. Emerg Infect Dis. 2003;9:1070-6.

25. Pini N. Hantavirus pulmonary syndrome in Latin America. Curr Opin Infect Dis 2004; $17: 427-31$

26. Raboni SM, de Borba L, Hoffmann FG, de Noronha L, Azevedo Ml, Carstensen S, et al. Evidence of circulation of Laguna Negra-like hantavirus in the Central West of Brazil: case report. J Clin Virol. 2009;45:153-6.

27. Souza WM, Machado AM, Figueiredo LTM, Boff E. Serosurvey of hantavirus infection in humans in the border region between Brazil and Argentina. Rev Soc Bras Med Trop. 2010;44:131-5.

28. Suzuki A, Bisordi I, Levis S, Garcia J, Pereira LE, Souza RP, et al. Identifying rodent hantavirus reservoirs, Brazil. Emerg Infect Dis. 2004;10:2127-34.

29. Williams RJ, Bryan RT, Mills JN, Palma RE, Vera I, Velasquez FD, et al. An outbreak of hantavirus pulmonary syndrome in western Paraguay. Am J Trop Med Hyg. $1997 ; 57: 274-82$

Received: 13 February 2012

Accepted: 9 April 2012 